\title{
NOVEL CORONAVIRUS (2019-nCoV): DISEASE BRIEFINGS
}

\author{
KANAAN AL-TAMEEMI ${ }^{1 *}$, RAIAAN KABAKLI ${ }^{2}$
}

${ }^{1}$ Department of Microbiology, Faculty of Pharmacy, Al Andalus University for Medical Sciences, Tartous, Syria. ${ }^{2}$ Department of Basic Sciences, Faculty of Pharmacy, Al Andalus University for Medical Sciences, Tartous, Syria. Email: d_knaan@yahoo.com

Received: 06 March 2020, Revised and Accepted: 11 April 2020

ABSTRACT

Coronavirus (CoV) (2019-nCoV) is a large, enveloped, positive-sense, single-stranded RNA virus. The abnormal outbreak of 2019-nCoV in Wuhan warns of the risk of $\mathrm{CoV}$ (2019-nCoV) to public health which causes viral pneumonia outbreak. In our review, we will discuss the biology of CoVs and the potential risk of the novel $\mathrm{CoV}$ (2019-nCoV) and guide us to strategic objectives for controlling the virus.

Keywords: Coronavirus (2019-nCoV), Outbreak, Wuhan, Enveloped RNA virus.

(C) 2020 The Authors. Published by Innovare Academic Sciences Pvt Ltd. This is an open access article under the CC BY license (http://creativecommons. org/licenses/by/4. 0/) DOI: http://dx.doi.org/10.22159/ajpcr.2020.v13i5.37436

\section{INTRODUCTION}

Coronaviruses (CoVs) constitute a worldwide health threat. In the years 2002-2003, severe acute respiratory syndrome CoV (SARS-CoV) affected more than 8000 people in 26 countries [1]. Since September 2012, the WHO has been notified of 2494 cases of Middle East respiratory syndrome CoV (MERS-CoV) 858 associated deaths have occurred [2]. In 2019, an outbreak of novel CoV happened in Wuhan, China and continued to expand. Due to the appearance of thousands of new cases in China, a "public health emergency of international concern (PHEIC)" was declared on 30 of January by the World Health Organization.

CoVs cause respiratory and gastrointestinal symptoms in humans and other animals; they have the ability for adapting to new environments through mutation and hence are programmed to alter the host tissue efficiency $[3,4]$. As a result, health complications from CoVs continue for the long term.

According to the WHO reports on April 4, 2020 (Situation Report -75) [5], there are globally 1,051,635 confirmed cases (79,332 new), in China, there are 82875 confirmed cases (73 new), 3335 deaths (4 new). Outside of China, the highest rate was in the United States of America $(241,703$ cases with 5854 deaths) followed by Italy $(119,827$ cases with 14,681 deaths $)$ and Spain $(117,710$ cases with 10,935 deaths), then Iran (53,183 cases with 3294 deaths), Republic of Korea (10,156 cases with 177 deaths) while the number of reported cases in the Arab countries was as follows: Saudi Arabia (2039 cases with 25 deaths), United Arab Emirates (1264 cases with nine deaths), and Qatar (1075 cases with three deaths) (Fig. 1).

Novel CoV has been identified in patients who suffered from acute respiratory disease. The outbreak appeared in Wuhan, China, and indicated human-to-human transmission. Cases associated with Travel have been reported in a few other countries. On January 30, 2020, according to the potential effects of 2019-nCoV infection, the WHO declared this epidemic as a "PHEIC [6] ."

In the early stages of $2019 \mathrm{nCoV}$ outbreak in Wuhan, cases of infected people were reported to those who were linked to seafood and live animal market, suggesting two points: The infection was spread from animal to human and the likely zoonotic origin of the COVID-19. Genomic sequence analysis showed 88\% of COVID-19 symmetry with two bat-derived respiratory syndromes (SARS), indicating the most likely link between COVID-19 and humans [7-9]. Later, a growing number of patients indicated that the spread was human-tohuman [10] Epidemiological evidence shows that it can be transmitted from human-to-human through droplets, personal contact, and contaminated objects [11].

\section{CLASSIFICATION AND VIRION STRUCTURE}

The classification of CoVs is based on similarities in their genomic sequence, genomic organization, replication strategies, antigenic properties of viral proteins, structural characteristics of virions, and physicochemical and pathogenic properties $[12,13]$.

CoVs belong to Coronaviridae and subfamily Coronavirinae that include four genera: Alpha CoV (ex. human CoV NL63, porcine CoV TGEV), Beta $\mathrm{CoV}$ (ex. SARS-CoV, MERS-CoV, novel CoV nCoV, bat CoV HKU4), Gamma $\mathrm{CoV}$ (ex. IBV), and Delta CoV (ex. PdCV) [14,15].

Mutations rates in RNA viruses are greater than in DNA viruses, suggesting a more ability of adaptation for survival.

In general, CoVs are large enveloped RNA viruses. They have the largest genome among all RNA viruses (ranging 27-32 kb) with 5'-cap structure and 3'poly-A tail acts as mRNA [16].

CoVs are spherical virions with diameters of approximately $125 \mathrm{~nm}$ based on cryoelectron tomography and cryoelectron microscopy [17-19] with distinct "club-like" protrusions formed by the spike protein (Figs. 2 and 3) [20-22].

There are four main structural proteins: Spike glycoprotein (S): These proteins radiate from the lipid envelope of the virus and give it the solar corona (crown-like) appearance under the electron microscope. They play an important role in the binding of host cell receptors and entering into it $[23,24]$. Membrane protein (M) and envelope protein (E) which are involved in virus assembly, nucleocapsid protein $(\mathrm{N})$ which is joined to RNA genome to make nucleocapsid, in addition to other proteins which are play roles in replication of the virus and facilitate entry into host cells $[14,19,25,26]$.

\section{CoV LIFE CYCLE}

The S protein is divided into two functionally distinct subunits: The S1 subunit which is involved in receptor recognition, and the S2 subunit which promotes membrane fusion and (S) into the viral membrane (Fig. 4). The initial $\mathrm{CoV}$ infection begins with the attachment of the S1 of the spike protein with its appropriate receptor. 


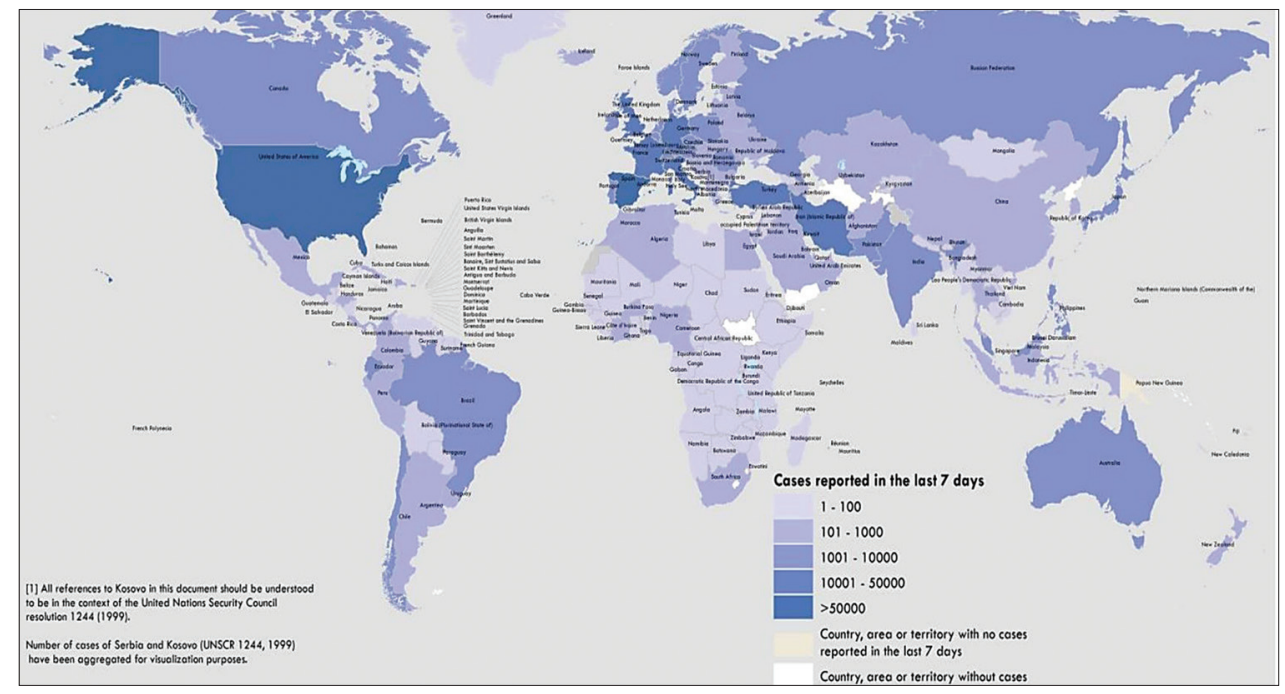

Fig. 1: Distribution of coronavirus around the world [5]

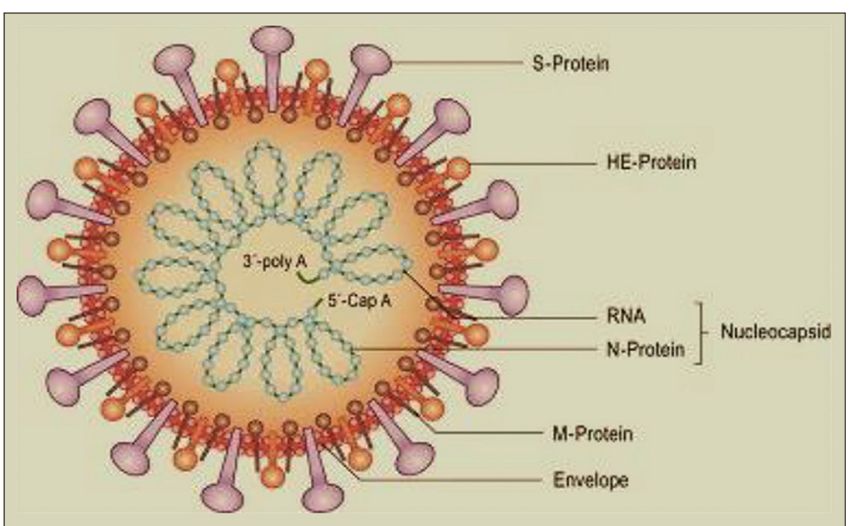

Fig. 2: Main structure of coronavirus (2019-nCoV) [27]

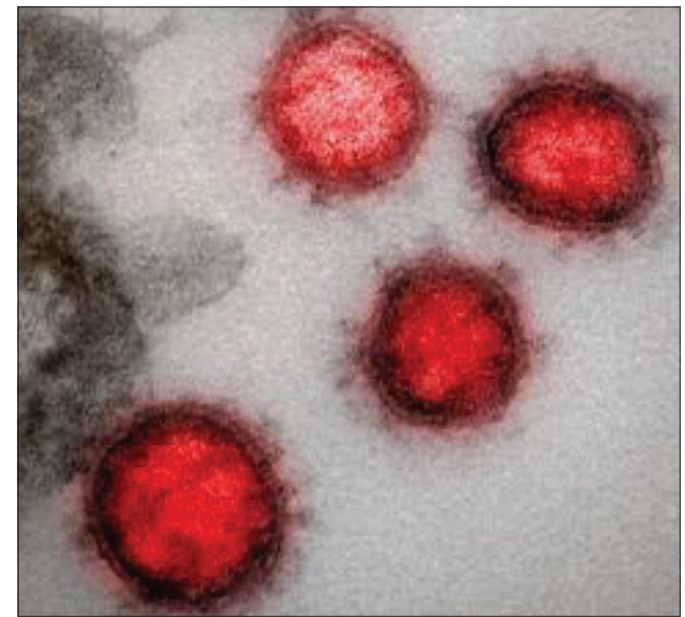

Fig. 3: Electron-microscope image of COVID-19, now known SARS-CoV-2. Image produced by National Institute of Allergy and Infectious Disease, US. Credit: National Institute of Allergy and Infectious Diseases (NIAID)-RML/de Wit/Fischer [28]

After the binding with receptors, the virus accesses the cytosol of a host cell by cleavage of $\mathrm{S}$ protein (at two sites in S2 subunit) by a cathepsin or another protease, then followed by fusion of the viral and cellular membranes $[14,17,29]$.
Following the entering of the virus into the host cell and releasing of the nucleocapsid to the cell cytosol, the viral RNA is translated to produce polyproteins (pp1a, pp1ab). pp1a and pp1ab are processed by proteases to make 16 non-structural proteins (NSPs), which will be assembled later to form the replicase-polymerase which is involved in viral replication where the genomic RNA is replicated, the subgenomic RNA will be transcribed and translated to produce the structural proteins [22] E, S, and $M$ which are translated and inserted into the endoplasmic reticulum. These proteins pass to the ER-Golgi intermediate compartment (ERGIC) [30,31]. There, viral genomes are encapsidated by $\mathrm{N}$ protein bud out the membranes of the ERGIC containing the structural proteins of virus forming mature virion (Fig. 5).

In some of the CoVs, $\mathrm{S}$ protein (that is not assembled) passes to the cell surface where it mediates the fusion between infected cells and adjacent uninfected cells leading to produce big multinucleated cells, and this allows the virus to spread within the infected body without being detected by virus antibodies $[14,32]$.

\section{TRANSMISSION}

The virus spreads out from person to person through the respiratory droplets which form when the patient coughs or sneezes. These droplets fall inside the noses or mouths of nearby people or maybe inhaled to their lungs. The transmission may also occur by direct contact with contaminated objects or surfaces, followed by touching the face. Furthermore, continuous travel into and out of infected countries contributes to the outbreak of the virus $[9,24,35-38]$

In previous studies conducted on women with $\mathrm{CoV}$ (in the third trimester of pregnancy), the results showed that there was no evidence of the transmission from mother to her child. All pregnant mothers underwent cesarean sections; therefore, it remains difficult knowing whether transmission can occur during vaginal birth $[9,39]$.

\section{CLINICAL SIGNS AND PATHOLOGICAL CHANGES}

The incubation period of COVID-19 is about 15 days from infection acquisition. The symptoms appear approximately in the $5^{\text {th }}$ day, the period from the appearance of COVID-19 symptoms to death ranged from 6 to 41 days [40]. This period depends on the age of the patient and the status of the patient's immune system [9].

COVID-19 replicates efficiently in the upper respiratory tract with fewer symptoms, also it has an affinity to cells in the lower respiratory tract where replication takes place. We can distinguish three major patterns of symptoms according to the level of infection: 
- Moderate infection with upper respiratory tract symptoms

- Non-life threatening pneumonia

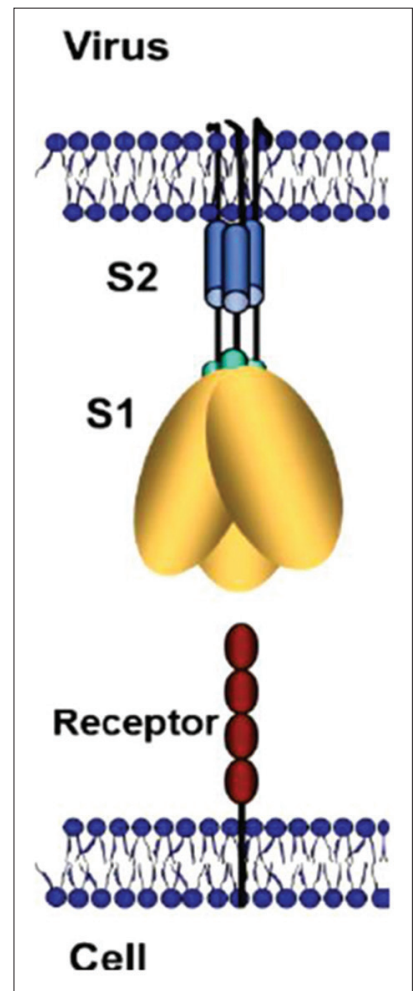

Fig. 4: Structure of spike glycoprotein (S) [33]
- Awful pneumonia with acute respiratory distress syndrome that begins with a few symptoms lasting for 7-8 days then advances to the rapid deterioration [38].

Clinically, patients with COVID-19 pneumonia suffer from fever with/ or without chills, chest tightness, shortness of breath, dry cough, headache, and sweating [9,24,28,36,41-43] Previous research showed that the human angiotensin-converting enzyme 2 (ACE2) is the receptor for 2019-nCoV [5,6]. In addition, other studies reported the high expression of ACE2 in the kidney, testicular tissue, and kidney damage in patients with 2019-nCoV-infected [29,44,45].

Pathological changes are summarized as follows: In lungs, it was noted that the bronchi were filled with desquamated epithelial cells and mucus, hyperplastic of alveolar epithelial cells, the formation of hyaline membrane, appearance of hemorrhagic and necrotic foci on lungs, and bilateral ground-glass opacities on chest computed tomography scans. In addition to a shrinking of the spleen, enlarging of the dark-red liver with the appearance of necrotic foci, lymphocytopenia, pancytopenia in bone marrow, necrosis in spleen, and lymph nodes, it was also observed degeneration in heart cells, endovasculitis, and thrombus formation. In the kidney, exudation of protein in the Bowman's capsule, hyaline casts, and fibrotic foci in kidney interstitium was seen. In addition to the appearance of: cerebral edema, neurons degeneration, necrosis of adrenal glands and epithelium mucosa desquamation in the digestive system $[9,46]$.

\section{DIAGNOSIS}

Laboratory diagnosis of $\mathrm{CoV}$ infections relies on collecting of specimens from the upper respiratory tract (nasopharyngeal and oropharyngeal swab) and the lower respiratory tract (tracheal aspirate, sputum, or bronchoalveolar lavage) [47,48]. Additional

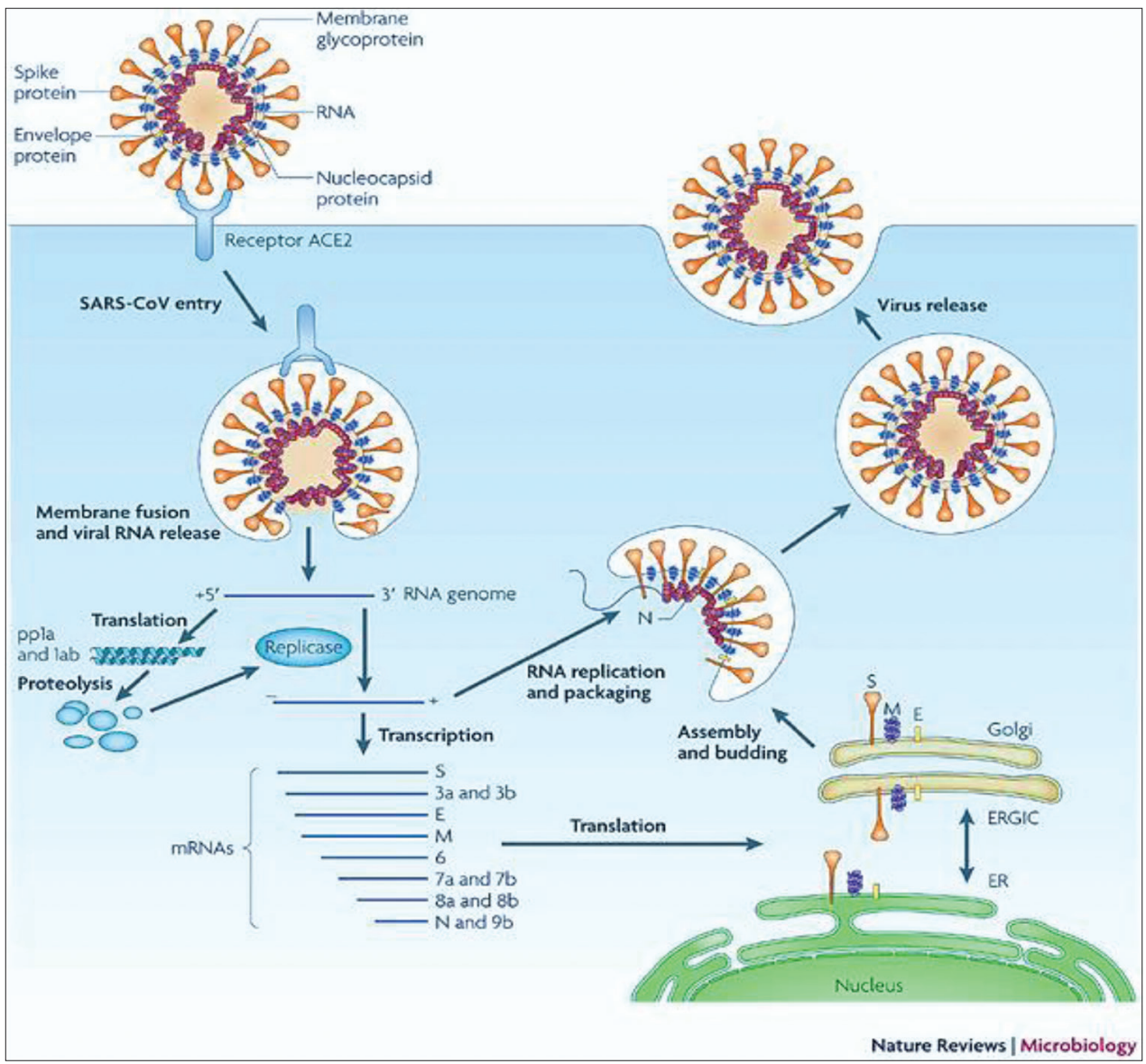

Fig. 5: Coronavirus life cycle [34] 
specimens can also be collected from stool or urine, plus reduced lymphocytes count [49]. Molecular diagnosis can also achieve early detection of $2019 \mathrm{n}-\mathrm{CoV}$ in human samples allowing rapid identification of patients [50].

The most important methods used in the diagnosis are nucleic acid test by detection of the viral sequence by real-time (RT)-polymerase chain reaction, in addition to serologic diagnosis combined with immunochromatography, also imaging technology where the chest radiograph is important in COVID-19 diagnosis, it allows to see the bilateral distribution of shadows the ground-glass opacity [51].

\section{TREATMENT}

The treatment stage goes through several steps, as follows:

- Immediate isolated for suspected cases

- Continuous monitoring of their water and electrolyte balance and oxygen rates

- According to the severity of the infection, monitoring of many points should be done such as urine routine, liver enzyme, c-reactive protein, coagulation function, and arterial blood gas analysis

- In critical cases, oxygen must be given by nasal catheter and mask oxygenation. If the case does not improve within $1-2 \mathrm{~h}$, tracheal intubation, and invasive mechanical ventilation should be used

- Antiviral therapy: There are a few options for COVID-19 treatment. Until now, no recommended drugs or vaccine can be used in treatment programs. At present, people with COVID-19 must receive help and care to reduce symptoms as much as possible. In acute cases, treatment should include care to support vital functions of organs $[35,52]$.

Previous studies reported the efficiency of types I and II interferons in reducing in vitro MERS-CoV replication [53]. The use of a combination of lopinavir and ritonavir, pegylated interferon, and ribavirin provided a successful viral treatment [54]. In vitro studies have shown that viral RNA transcription was stopped with remdesivir using in an early stage of infection [9,36,55-59].

It was reported that chloroquine and hydroxychloroquine, which are known as an anti-malarial drug, are used as an effective drug for SARS$\mathrm{CoV} 2$, it is believed that they play an important role in virus assembly inhibition, viral protein glycosylation inhibition causing ACE-2-SARS$\mathrm{CoV}$ interaction less efficient, viral RNA polymerase inhibition, ACE2 cellular receptor inhibition and many viral processes [60-64]. The treatment protocol was enhanced using azithromycin, although its direct effects on the virus are uncertain, it plays a role in reducing pulmonary inflammatory disorders and cytokine storm, but caution is advised when using these drugs in patients who suffer from renal failure, hepatic disease or who are taking medications that might interact causing arrhythmias $[51,61,65]$.

- Blood purification: The perfusion and blood/plasma filtration can reduce cytokine production and inflammatory reactions. It used in severe and critical cases [46]

- COVID-19 convalescent plasma: It is suitable in case of rapid disease progression. Studies showed patients with severe respiratory failure and were receiving mechanical ventilation had received plasma treatment and their health had improvement after 1 week of transfusion. The plasma was obtained from donors who had recovered from SARS-CoV-2 infections, this plasma had IgG and IgM anti-SARS-CoV-19 antibodies, it was noticed that after the transfusion of convalescent plasma, and the titers of IgG and IgM in the sera of patients increased at 7 days after transfusion

- Vaccines: Until now, there is no safe vaccine that has been declared which has completed the clinical trials. Many companies and academic institutions are racing to produce this vaccine. There are about 50 vaccine candidates under development. According to the declaration of the American National Institute of Health, a vaccine developing has begun at Kaiser Permanente Washington Health Research Institute in Seattle funding by the NIAID.
The study evaluates different doses of mRNA-1273 vaccine after it has shown promise results in animal models, on 45 healthy volunteers' ages 18-55 years. The first participant received the investigational vaccine on March 16, 2020. With these attempts, the World Health Organization declared that it did not expect a vaccine against SARS-CoV-2 to become available in $<18$ months [66]

\section{PREVENTION}

Recommendations must be adhered to prevent the potential spread of COVID-19 such as $[9,28,36,63,53,67]$.

- Avoid population density

- Avoid moving to areas which are endemic with (COVID-19) has occurred

- Stay at home as possible. Wearing face masks to prevent the spread of droplets if needing to go out home

- Avoiding any contact with individuals who show any symptoms of respiratory illness

- Handwashing with soap and water for $20 \mathrm{~s}$ or use alcohol (70\%) to disinfect touched objects and things, and avoiding touching the face and eyes

- Covering mouth and nose when coughing and sneezing

- Avoid sharing personal items

- Keep the ailing in a separate room and avoid contact him without wearing gloves and face masks.

\section{CONCLUSION}

Chinese CDC and the Wuhan Municipal Health Commission provide us with the regular updates of confirmed case numbers and patient statuses, enabling public health authorities to observe the outbreak of the disease in RT. Researchers from around the world have connected to study the updated data and highlight on unknown information about the outbreak of virus, allowing rapid response by researchers. While there are many unknown facts with $2019-\mathrm{nCoV}$, the world is interesting and prepared to battle the newest emergent virus strain.

\section{AUTHORS' CONTRIBUTIONS}

Both authors have contributed to the preparation of this review and editing of the manuscript.

\section{CONFLICTS OF INTEREST}

There are no conflicts of interest.

\section{AUTHORS' FUNDING}

No funding.

\section{REFERENCES}

1. Avialble from: https://www.who.int/ith/diseases/sars/en.

2. Avialble from: https://www.who.int/emergencies/mers-cov/en

3. Graham RL, Baric RS. Recombination, reservoirs, and the modular spike: Mechanisms of coronavirus cross-species transmission. J Virol 2010;84:3134-46.

4. Li WH, Wong SK, Li F, Kuhn JH, Huang IC, Choe H, et al. Animal origins of the severe acute respiratory syndrome coronavirus: Insight from ACE2-S-protein interactions. J Virol 2006;80:4211-9.

5. Coronavirus Disease 2019 (COVID-19) Situation Report-75, WHO, Data as Reported by National Authorities by No. 10:00CET4; 2020.

6. Shen K, Yang Y. Diagnosis and treatment of 2019 novel coronavirus infection in children: A pressing issue. World J Pediatr 2020. DOI: 10.1007/s12519-020-00344-6.

7. Lu R, Zhao X, Li J, Niu P, Yang B, Wu H, et al. Genomic characterisation and epidemiology of 2019 novel coronavirus: Implications for virus origins and receptor binding. Lancet 2020;395:565-74.

8. Wan Y, Shang J, Graham R, Baric RS, Li F. Receptor recognition by a novel coronavirus from Wuhan: An analysis based on decade-long structural studies of SARS coronavirus. J Virol 2020;94:1-9.

9. Rothana HA, Byrareddy SN. The epidemiology and pathogenesis of coronavirus disease (COVID-19) outbreak. J Autoimmun 2020;109:102433. 
10. Available from: https://www.cdc.gov/coronavirus/2019-ncov/ summary.html? cdc aa refval=https $\% 3 \mathrm{a} \% 2 \mathrm{f} \% 2 \mathrm{fwww} . \mathrm{cdc}$. gov $\% 2$ fcoronavirus $\% 2$ f 2019 -ncov $\% 2$ fabout $\% 2$ fwhat-you-should-do. html\#anchor_1580064337377.

11. World Health Organization. 2019 Novel Coronavirus $(2019 \mathrm{nCoV})$ : Strategic Preparedness and Response Plan. Geneva: World Health Organization, 2020 Some Rights Reserved; 2020.

12. Tok TT, Tatar G. Structures and functions of coronavirus proteins: Molecular modeling of viral nucleoprotein. Int J Virol Infect Dis 2017;2:1-7.

13. Lai MM, Cavanagh D. The molecular biology of coronaviruses. Adv Virus Res 1997;48:1-100.

14. Li F. Structure, function, and evolution of coronavirus spike proteins. Annu Rev Virol 2016;3:237-61.

15. Phan MT, Tri TN, Anh PH, Baker S, Kellam P, Cotton M, et al. Identification and characterization of Coronaviridae genomes from Vietnamese bats and rats based on conserved protein domains. Virus Evol 2018;4:1-12.

16. Chen Y, Liu Q, Guo D. Emerging coronaviruses: Genome structure, replication, and pathogenesis. J Med Virol 2020;92:418-4231.

17. Fehr AR, Perlman S. Coronaviruses: An overview of their replication and pathogenesis. Methods Mol Biol 2015;1282:1-23.

18. Barcena M, Oostergetel GT, Bartelink W, Faas FG, Verkleij A, Rottier PJ, et al. Cryo-electron tomography of mouse hepatitis virus: Insights into the structure of the coronavirion. Proc Natl Acad Sci U S A 2009;106:582-7.

19. Neuman BW, Adair BD, Yoshioka C, Quispe JD, Orca G, Kuhn P, et al. Supramolecular architecture of severe acute respiratory syndrome coronavirus revealed by electron cryomicroscopy. J Virol 2006;80:7918- 28 .

20. Lim YX, Ng YL, Tam JP, Liu DX. Human coronaviruses: A review of virus-host interactions. Diseases 2016;4:26.

21. Kolesnikova L, Slenczk W, Brodt H, Klenk H, Becker S. Electron microscopy in diagnostics of SARS case. Microse Microanal 2003;9:438-9.

22. Marsolais G, Berthiaume L, DiFranco E, Marois P. Rapid diagnosis by electron microscopy of avian coronavirus infection. Can J Comp Med 1971;35:285-8.

23. Bárcena M, Oostergetelb GT, Bartelinkc W, Faasa FG, Verkleijd A, Rottierc PJ, et al. Cryo-electron tomography of mouse hepatitis virus: Insights into the structure of the coronavirion. PNAS 2009;106:582-7.

24. Clarivate Analytics Solution. Disease Briefing: Coronaviruses. Philadelphia, PA: Clarivate Analytics; 2020.

25. Schoeman D, Fielding BC. Coronavirus envelope protein: Current knowledge. Virol J 2019;16:69.

26. Seah I, Su X, Lingam G. Revisiting the dangers of the coronavirus in the ophthalmology practice. Eye (Lond) 2020. DOI: 10.1038/s41433020-0790-7.

27. Available from: http://www.ceepc.eu/node/19.

28. Chhikara BS, Rathi B, Singh J, Poonam P. Corona virus SARS-CoV-2 disease COVID-19: Infection, prevention and clinical advances of the prospective chemical drug therapeutics. Chem Biol Lett 2020;7:63-72.

29. Baltimore D, Ding S, Doherty PC, Fazakerly J, Gross HJ, Harrison BD, et al. Advances in Virus Research. $1^{\text {st }}$ ed., Vol. 96. Amsterdam: Elsevier Inc.; 2016.

30. Krijnse-Locker J, Ericsson M, Rottier PJ, Griffiths G. Characterization of the budding compartment of mouse hepatitis virus: Evidence that transport from the RER to the Golgi complex requires only one vesicular transport step. J Cell Biol 1994;124:55-70.

31. Tooze J, Tooze S, Warren G. Replication of coronavirus MHV-A59 in sac-cells: Determination of the first site of budding of progeny virions. Eur J Cell Biol 1984;33:281-93.

32. de Haan CA, Rottier PJ. Molecular interactions in the assembly of coronaviruses. Adv Virus Res 2005;64:165-230

33. Heald-Sargent T, Gallagher T. Ready, set, fuse! The coronavirus spike protein and acquisition of fusion competence. Viruses 2012;4:557-80.

34. Wit E, Doremalen N, Falzarano D, Munster VJ. SARS and MERS: Recent insights into emerging coronaviruses. Nat Rev Microbiol 2016;14:523-34

35. PAHO, WHO. Epidemiological Update Novel Coronavirus (COVID-19). Geneva: PAHO, WHO; 2020

36. Sahin AR, Erdogan A, Agaoglu PM, Dineri Y, Cakirci AY, Senel ME, et al. 2019 Novel coronavirus (COVID-19) outbreak: A review of the current literature. Eurasian J Med Oncol 2020;4:1-7.

37. Ministry of Health Infectious Diseases Protocol. Appendix A: DiseaseSpecific Chapters, Diseases Caused by a Novel Coronavirus, Including
Severe Acute Respiratory Syndrome (SARS) and Middle East Respiratory Syndrome (MERS); 2020.

38. Kansas Department of Health and Environment. Novel Coronavirus FAQs. United States: Kansas Department of Health and Environment; 2020.

39. Heymann DL, Shindo N, On Behalf of the WHO Scientific and Technical Advisory Group for Infectious Hazards. COVID-19: What is next for public health? Lancet 2020;395:542-5.

40. Wang W, Tang J, Wei F. Updated understanding of the outbreak of 2019 novel coronavirus (2019-nCoV) in Wuhan, China. J Med Virol 2020;92:441-7.

41. Bogoch II, Watts A, Thomas-Bachli A, Huber C, Khan K. Pneumonia of unknown aetiology in wuhan, China: Potential for international spread via commercial air travel. J Trav Med 2020;27:taaa008.

42. Lu H, Stratton CW, Tang YW. Outbreak of pneumonia of unknown etiology in Wuhan, China: The mystery and the miracle. J Med Virol 2020;92:401-2.

43. Zhao S, Lin Q, Ran J, Musa SS, Yang G, Wang W, et al. Preliminary estimation of the basic reproduction number of novel coronavirus (2019-nCoV) in China, from 2019 to 2020: A data-driven analysis in the early phase of the outbreak. Int J Infect Dis 2020;92:214-7.

44. Fan C, Li K, Ding Y, Lu W, Wang J. ACE2 Expression in Kidney and Testis May Cause Kidney and Testis Damage After 2019-nCoV Infection; 2020 .

45. Li Z, Wu M, Guo J, Yao J, Liao X, Song S. Caution on Kidney Dysfunctions of 2019-nCoV Patients; 2020.

46. National Health Commission and State Administration of Traditional Chinese Medicine. Diagnosis and Treatment Protocol for Novel Coronavirus Pneumonia. Beijing: The General Office of National Health Commission; 2020.

47. World Health Organization. Laboratory Biosafety Guidance Related to the Novel Coronavirus 2019-nCoV, Interim Guidance. Geneva: World Health Organization; 2020

48. World Health Organization. Aboratory Testing of Human Suspected Cases of Novel Coronavirus ( $\mathrm{nCoV}$ ) Infection Interim Guidance. Geneva: World Health Organization; 2020.

49. Xiao S, Wu Y, Liu H. Evolving status of the 2019 novel coronavirus infection: Proposal of conventional serologic assays for disease diagnosis and infection monitoring. J Med Virol 2020;92:464-7.

50. Chu DK, Pan Y, Cheng SM, Hui KP, Krishnan P, Liu Y, et al. Molecular diagnosis of a novel coronavirus (2019-nCoV) causing an outbreak of pneumonia. Clin Chem 2020;66:549-55.

51. Jin Y, Yang H, Ji W, Wu W, Chen S, Zhang W, et al. Virology, epidemiology, pathogenesis, and control of COVID-19. Viruses 2020;12:E372

52. Available from: https://www.cdc.gov/coronavirus/2019-ncov/about/ prevention-treatment.html.

53. Hui DS, Azhar EI, Madani TA, Ntoumi F, Kock R, Dar O, et al. The continuing 2019-nCoV epidemic threat of novel coronaviruses to global health-the latest 2019 novel coronavirus outbreak in Wuhan, China. Int J Infect Dis 2020;91:264-6.

54. Chen N, Zhou M, Dong X, Qu J, Gong F, Han Y, et al. Epidemiological and clinical characteristics of 99 cases of 2019 novel coronavirus pneumonia in Wuhan, China: A descriptive study. Lancet 2020;395:507-13.

55. Warren TK, Jordan R, Lo MK, Ray AS, Mackman RL, Soloveva V, et al. Therapeutic efficacy of the small molecule GS-5734 against Ebola virus in rhesus monkeys. Nature 2016;531:381-5.

56. Jordan PC, Liu C, Raynaud P, Lo MK, Spiropoulou CF, Symons JA, et al. Initiation, extension, and termination of RNA synthesis by a paramyxovirus polymerase. PLoS Pathog 2018;14:e1006889.

57. Cockrell AS, Yount BL, Scobey T, Jensen K, Douglas M, Beall A, et al. A mouse model for MERS coronavirus-induced acute respiratory distress syndrome. Nat Microbiol 2016;2:16226.

58. Brown AJ, Won JJ, Graham RL, Dinnon KH $3^{\text {rd }}$, Sims AC, Feng JY, et al. Broad spectrum antiviral remdesivir inhibits human endemic and zoonotic deltacoronaviruses with a highly divergent RNA dependent RNA polymerase. Antiviral Res 2019;169:104541.

59. Paules CI, Marston HD, Fauci AS. Coronavirus infections-more than just the common cold. JAMA 2020;323:707-8.

60. Gautret P, Lagier J, Parola P, Hoang T, Meddeb L, Mailhe M, et al. Hydroxychloroquine and azithromycin as a treatment of COVID-19: Results of an open-label non-randomized clinical trial. Int J Antimicrob Agents 2020;105949. DOI: 10.1016/j. ijantimicag.2020.105949.

61. Smith T, Bushek J, Prosser T. COVID-19 Drug Therapy-Potential Options. Amsterdam: Elsevier; 2020.

62. Rabi FA, Al Zoubi MS, Kasasbeh GA, Salameh DM, Al-Nasser AD. 
SARS-CoV-2 and coronavirus disease 2019: What we know so far. Pathogens 2020;9:E231

63. Cascella M, Rajnik M, Cuomo A, Dulebohn SC, Napoli R. Features, Evaluation and Treatment Coronavirus (COVID-19). Treasure Island, FL: StatPearls Publishing; 2020.

64. Wang M, Cao R, Zhang L, Yang X, Liu J, Xu M, et al. Remdesivir and chloroquine effectively inhibit the recently emerged novel coronavirus
(2019-nCoV) in vitro. Cell Res 2020;30:269-71.

65. Available from: https://www.cdc.gov/coronavirus/2019-ncov/hcp/ therapeutic-options.html

66. Available from: https://www.nih.gov/news-events/news-releases/nihclinical-trial-investigational-vaccine-covid-19-begins.

67. World Health Organization. Coronavirus Disease 2019 (COVID-19) Situation Report No. 36. Geneva: World Health Organization; 2020. 